\title{
TAMPILAN INDUK KAMBING PERANAKAN ETTAWAH YANG DIBERI CAMPURAN BEBERAPA HIJAUAN
}

\author{
Rantan Krisnan ${ }^{1}$ dan Rahman ${ }^{2}$ \\ ${ }^{1}$ Balai Penelitian Ternak, Bogor, 16720, ran_tania@yahoo.com \\ ${ }^{2}$ Fakultas Peternakan, Universitas Halu Oleo Kendari, rahman@uho.ac.id.
}

\begin{abstract}
ABSTRAK
Penelitian bertujuan untuk mengevaluasi pengaruh pemberian campuran hijauan terhadap tampilan (kinerja) induk kambing Peranakan Etawah (PE). Sebanyak 48 ekor induk kambing PE dengan bobot awal sebesar 39,65 $\pm 2,24 \mathrm{~kg}$ dibagi menjadi 2 kelompok (kontrol dan perlakuan). Pakan dasar yang diberikan adalah rumput Raja ad libitum, $700 \mathrm{~g} / \mathrm{h} / \mathrm{e}$ konsentrat (PK 15,34\% and TDN 66,30\%), sedangkan kelompok perlakuan mendapatkan tambahan $500 \mathrm{~g} / \mathrm{h} / \mathrm{e}$ hijauan. Campuran hijauan yang digunakan merupakan campuran daun-daunan antara lain daun mindi, daun nangka, daun kiacret, daun kaliandra dan daun kelor. Parameter yang diukur adalah konsumsi harian nutrien pakan yaitu bahan kering (BK), protein kasar (PK), energi kasar (EK), serat deterjen neutral (SDN), serat deterjen asam (SDA), kalsium (Ca) dan fosfor (P).Data dianalisis menggunakan LS Means Proc GLM, SAS.Hasil menunjukkan bahwa pemberian tambahan campuran hijauan tidak mempengaruhi ( $p>0.05)$ konsumsi harian, namun mempengaruhi $(p<0.05)$ konsumsi harian nutrient pakan, PBBH dan rasio konversi pakan (RKP). Konsumsi harian PK dan TDN untuk kelompok perlakuan adalah 153,25 g dan 717,78 g, sedangkan kelompok kontrol adalah 131,35 g dan 699,96 g. Besarnya PBBH dan RKP adalah 95,54 g dan 11,28; 76,13 g dan 13,96 untuk masing-masing kelompok perlakuan dan kontrol. Disimpulkan bahwa penambahan campuran hijauan pakan dapat meningkatkan tampilan (performance) yang labih baik pada induk kambing PE.
\end{abstract}

Kata kunci: Campuran hijauan, Induk kambing PE, Performan

\begin{abstract}
A study was conducted to evaluate the effect of forage mixtures to performance of Ettawa Crossbreed (EC) doe goats. Forty eight heads EC doe goats with a weight of $39.65 \pm 2.24 \mathrm{~kg}$ were divided into 2 groups (control and treatment). The experimental design was a group randomized design.Basic feed consists of ad libitumKinggrass and $700 \mathrm{gr} / \mathrm{d}$ concentrates (CP $15.34 \%$ and $66.30 \% \mathrm{TDN}$ ), while the treatment group receive an additional $500 \mathrm{~g} / \mathrm{d} / \mathrm{e}$ forage mixtures. Forage mixtures contain a mixture of leaves included Mindi leaves, jackfruit leaves, Kiacret leaves, calliandra leaves and Moringa leaves. The parameters measured were nutrientsdaily consumption which covered dry matter intake, crude protein, TDN, NDF, ADF, calcium and phosphor intake. The results shows that the additional forage mixture does not affect ( $p>0.05)$ to dry matter $(\mathrm{DM})$ daily consumption, however significantly influenced $(\mathrm{P}<0.05)$ against the nutrien daily consumption, daily gain and feed conversion ratio. Crude Protein and TDN daily consumption for the treatment group was $153.25 \mathrm{~g}$ and $717.78 \mathrm{~g}$, while the control group was $131.35 \mathrm{~g}$ and 699.96 g. The amount of daily gain and feed conversion ratio was $95.54 \mathrm{~g}$ and $11.28 ; 76.13 \mathrm{~g}$ and 13.96 for each treatment and control group. It was concluded that the addition of a forage mixture can improve the performace of Ettawa Crossbreed doe goats.
\end{abstract}

Key Words: Forage mixture, Ettawa Crossbreed doe goats, Performance 


\section{PENDAHULUAN}

Ternak kambing merupakan salah satu ternak pilihan yang sesuai untuk dikembangkan di Indonesia, mengingat ternak ini mempunyai kemampuan adaptasi yang tinggi dengan berbagai tipe iklim dan lingkungan. Kambing PE yang telah beradaptasi dengan lingkungan banyak dikembangkan sebagai ternak dwiguna, penghasil daging dan susu. Peternakan kambing perah mempunyai kontribusi terhadap ketahanan pangan dan menjadi sumber pendapatan peternak melalui komersialisasi daging, susu segar maupun produk olahan susu (Devendra 2012; Sutama 2014).

Dalam pengembangan kambing dwiguna yang efisien perlu didukung dengan pakan yang cukup dan berkualitas.Hijauan yang berupa daundaunan yang berasal dari legume (glirisidia, kaliandra, lamtoro) dan pohon-pohonan (nangka, mindi, mene-e) merupakan hijauan yang banyak diberikan pada ternak kambing maupun domba di pedesaan.Kualitas hijauannya tergantung pada beberapa hal, umumnya berhubungan dengan umur dan bagian tanaman dengan komposisi nutrientnya.Hijauan berupa daun-daunan tersebut mengandung protein diatas $20 \%$ dengan serat yang lebih rendah dari rumput-rumputan.Pemanfaatan hijauan jenis ini didukung pula oleh sifat kambing yang lebih menyukai daundaunan dibandingkan rumputrumputan.Namun dalam mengoptimalkan produksi kambing, perlu ditambahkan konsentrat pada pakannya dikarenakan ukuran sistem pencernaan kambing relative lebih kecil daripada sapi untuk memelihara kebutuhan energinya.

Pemberian pakan berupa campuran hijauan dan konsentrat dengan tingkat protein dan TDN yang tinggi dapat meningkatkan produktivitas ternak, sehingga produksi daging maupun susu akan optimal.Pada penelitian ini dievaluasi pengaruh pemberian campuran beberapa hijauan terhadap tampilan (kinerja) induk kambing Peranakan Etawah (PE).

\section{MATERI DAN METODE}

\section{Ternak dan manajemen pemeliharaan}

Percobaan menggunakan 48 ekor kambing induk laktasi multiparitas Peranakan Etawah (kambing PE), dengan rataan bobot awal 39,65 $\pm 2,24 \mathrm{~kg}$ yang dibagi menjadi 2 kelompok yaitu kelompok kontrol dan kelempok perlakuan.Kambing induk merupakan kambing paritas ke tiga sampai ke empat.Ternak dikandangkan secara grup dengan masing-masing perlakuan terdiri dari 6 grup dimana masing-masing grup terdiri dari 4 ekor. Pakan dasar yang diberikan kepada ternak kelompok kontrol adalah cacahan rumput Raja ad libitumdan $700 \mathrm{~g} / \mathrm{h} / \mathrm{e}$ konsentrat (PK 15,34\% dan TDN 66,30\%), sedangkan kelompok perlakuan mendapatkan tambahan $500 \mathrm{~g} / \mathrm{h} / \mathrm{e}$ hijauan. Hijauan yang digunakan merupakan campuran daun-daunan antara lain daun mindi, daun nangka, daun kiacret, daun kaliandra dan daun kelor dengan proporsi yang tidak ditentukan. Konsentrat yang dipergunakan adalah konsentrat kambing komersial.Konsentrat dan rumput diberikan sehari dua kali yaitu pagi dan sore. Air minum tersedia setiap saat melalui nipple.Konsumsi pakan diukur setiap hari dan ternak ditimbang setiap dua minggu.Komposisi rumput, campuran hijauan dan konsentrat ditampilkan pada Tabel 1.

Pengamatan dilakukan selama 10 minggu dengan parameter yang diukur adalah konsumsi harian nutrien pakan yaitu bahan kering (BK), protein kasar 
(PK), energi kasar (EK), serat deterjen neutral (SDN), serat deterjen asam (SDA), kalsium (Ca) dan fosfor (P). Rasio konsumsi rumput terhadap konsentrat dihitung dengan cara membandingkan besarnya konsumsi rumput terhadap konsentrat. Rasio konversi pakan (RKP) ditetapkan sebagai konsumsi BK terhadap peningkatan bobot badan.

\section{Analisis kimia pakan}

Rumput dan konsentrat dianalisis komposisi kimianya berdasarkan metode AOAC yang telah dimodifikasi di Laboratorium Balitnak. Bahan kering ditetapkan dengan pemanasan pada suhu $135^{\circ} \mathrm{C}$ selama 2 jam(method930.15, AOAC2005). Kadar PK (nitrogen $\times 6.25$ )ditetapkan secara destruksi Kjeldahl-mikro dan dilanjutkan dengan prosedur auto-analysis, menggunakan auto-analyzer Brand Luebe, Germany (method 990.02, AOAC2005). Nilai EK ditetapkan dengan kalorimeter bomb (Adiabatic Oxygen Bomb, Parr InstrumentCo.6400) menggunakan asam benzoat sebagai standard. Nilai EK. Kandungan SDN dianalisis menggunakan metoda AOAC (AOAC 1995). Kadar SDA diukur secara destruksi sample dengan larutan asamdeterjen (method 973.18, AOAC 2005). Kandungan $\mathrm{Ca}$ and $\mathrm{P}$ diukur dengan cara melarutkan sampel yang telah diabukan di dalam campuran asam $\mathrm{HCl}$ dan $\mathrm{HNO}_{3}$, kemudian $\mathrm{Ca}$ dan $\mathrm{P}$ ditetapkan masingmasing secara spktrofotometri menggunakan AAS Model Varian Spectra 220 (method 942.05, AOAC 2000) dan UV-VIS Spectrophotometer(method 965.17, AOAC2005).

\section{Rancangan percobaan dan analisis statistik}

Percobaan dirancang menggunakan Rancangan Acak Lengkap (RAL) dengandua perlakuan dan enam ulangan dengan empat ekor setiap ulangannya. Data yang diperoleh dianalisis keragamannya dengan Analisis of Variance (ANOVA) menggunakan General linier programming (GLP) program SAS, bila terdapat perbedaan yang nyata dilanjutkan dengan uji Duncan (Duncan's New Multiple Range Tests) (SAS 2002).

\section{HASIL DAN PEMBAHASAN}

\section{Komposisi nutrient pakan}

Hasil analisa terhadap komposisi nutrien rumput raja, campuran hijauan dan konsentrat ditampilkan pada Tabel 1.

Tabel 1. Komposisi nutrien hijauan dan konsentrat percobaan (\%)

\begin{tabular}{lccc}
\hline \multicolumn{1}{c}{ Nutrien } & Rumput Raja & $\begin{array}{c}\text { Campuran } \\
\text { hijauan }\end{array}$ & Konsentrat \\
\hline Protein kasar & 7.22 & 20.56 & 18.19 \\
Serat deterjen netral & 71.03 & 56.24 & 26.08 \\
Serat deterjen asam & 49.35 & 50.71 & 12.92 \\
Total digestible nutrients $(T D N)^{*}$ & 67.74 & 74.44 & 79.24 \\
Kalsium & 0.25 & 1.39 & 0.63 \\
Fosfor & 0.52 & 0.69 & 0.60 \\
\hline
\end{tabular}

*TDN dihitung berdasarkan NRC (1981) 
Umumnya campuran hijauan yang terdiri dari beberapa jenis hijauan menunjukkan profil nutrien yang lebih baik bila dibandingkan dengan rumput raja.Kandungan protein dari campuran hijauan hampir tiga kali lebih tinggi dibandingkan rumput raja.Begitu juga dengan kandungan TDN dan unsur mineral yang memperlihatkan numerik lebih baik pada campuran hijauan.Hal ini sejalan dengan hasil penelitian dari banyak sumber yang melaporkan bahwa kelompok hijauan yang berasal dari leguminosa mempunyai kandungan nutrisi yang lebih baik dibandingkan jenis rumput.

\section{Konsumsi harian nutrien}

Hasil analisa terhadap konsumsi harian nutrien pakan pada penelitian ini tersaji pada Tabel 2.

Tabel 2.Konsumsi nutrien pakan percobaan

\begin{tabular}{|c|c|c|c|c|c|}
\hline \multirow{2}{*}{$\begin{array}{l}\text { Parameter Konsumsi } \\
\text { (g/e/h) }\end{array}$} & \multicolumn{3}{|c|}{ Perlakuan } & \multicolumn{2}{|c|}{ Keterangan } \\
\hline & Kontrol & $\begin{array}{l}\text { (+) Campuran } \\
\text { hijauan }\end{array}$ & Rataan & SEM & Nilai $P$ \\
\hline Rumput Raja & $473.77 \pm 14.24$ & $288.44 \pm 11.26$ & 379.44 & 12.79 & $<0.0001$ \\
\hline Campuran hijauan & - & $173.9 \pm$ & - & - & - \\
\hline Konsentrat & $575.55 \pm 4.10$ & $595.03 \pm 4.59$ & 585.29 & & \\
\hline Total Bahan kering & $1049.32 \pm 13.75^{\mathrm{a}}$ & $1057.36 \pm 14.34^{\mathrm{a}}$ & 1053.63 & 14.13 & 0.078 \\
\hline Protein kasar (PK) & $131.35 \pm 1.28^{\mathrm{b}}$ & $153.25 \pm 1.53^{\mathrm{a}}$ & 142.55 & 1.43 & $<0.0001$ \\
\hline Total digestible nutrients (TDN) & $699.96 \pm 9.24^{\mathrm{b}}$ & $717.78 \pm 9.61^{\mathrm{a}}$ & 709.2 & 9.48 & $<0.0001$ \\
\hline Serat deterjen netral (SDN) & $845.27 \pm 10.20^{\mathrm{b}}$ & $882.31 \pm 11.78^{\mathrm{a}}$ & 864.35 & 11.08 & $<0.0001$ \\
\hline Serat deterjen asam (SDA) & $358.59 \pm 6.69^{\mathrm{b}}$ & $575.27 \pm 7.83^{\mathrm{a}}$ & 469.36 & 7.31 & $<0.0001$ \\
\hline Kalsium (Ca) & $7.25 \pm 0.05^{\mathrm{b}}$ & $9.23 \pm 0.07^{\mathrm{a}}$ & 8.26 & 0.06 & $<0.0001$ \\
\hline Fosfor $(\mathrm{P})$ & $6.09 \pm 0.05^{b}$ & $7.18 \pm 0.06^{\mathrm{a}}$ & 6.65 & 0.05 & $<0.0001$ \\
\hline
\end{tabular}

Data pada Tabel 2 menunjukkan bahwa pemberian capuran hijauan yang mengandung berbagai daun-daunan tidak mempengaruhi ( $p>0.05)$ konsumsi harian bahan kering (BK), namun mempengaruhi $(\mathrm{p}<0.05)$ konsumsi harian nutrient pakan (TDN, PK, SDN, SDA, $\mathrm{Ca}$ dan $\mathrm{P}$ ).Konsumsi harian bahan kering perlakuan dan kontrol masing-masing mencapai $1057.36 \pm 14.34$ dan 1049.32 \pm 13.75 .Rataan konsumsi harian BK hasil penelitian untuk kambing PEini ternyata lebih kecil daripada yang dianjurkan NRC (2007) yakni sebesar $1550 \mathrm{~g}$ untuk kambing perah dengan BB $40 \mathrm{~kg}$ pada masa bunting. Konsumsi BK ransum untuk induk kambing PE hasil penelitian ini setara dengan $2.45 \%$ untuk kontrol dan $2.49 \%$ untuk ternak perlakuandari rataan BB-nya. Nilai ini juga lebih rendah dari kisaran kebutuhan BK yang disarankan oleh NRC (2007) yakni sebesar $3.1 \%$ dari BB.Namun apabila melihat konsumsi harian nutrien pada percobaan ini telah mencukupi kebutuhan seperti dianjurkan oleh NRC (2007) kecuali TDN. Nilai berdasarkan NRC (2007) untuk konsumsi harian nutrien induk kambing bunitng seperti PK, TDN, Ca dan Pyaitu masing-masing adalah 135, 820, 6.2 dan $3.6 \mathrm{~g} / \mathrm{e} / \mathrm{h}$. Hal ini menunjukkan bahwa konsumsi 
nutrien pakan secara umum sudah mencukupi dan diharapkan tidak akan mengganggu kinerja ternak. Perbedaan yang nyata $(\mathrm{p}<0.05)$ juga terlihat pada konsumsi nutrien serat baik serat deterjen netral maupun serat deterjen asam.

\section{Pertambahan bobot badan dan konversi pakan}

Pemberian campuran beberapa hijauan memberikan pengaruh yang nyata $(\mathrm{p}<0.05)$ terhadap pertambahan bobot badan harian dan nilai konversi pakan induk kambing Peranakan Etawa seperti yang terlihata pada Tabel 3 .

Tabel 3.Pertambahan bobot badan harian dan konversi pakan

\begin{tabular}{|c|c|c|c|c|c|}
\hline \multirow{2}{*}{ Parameter Konsumsi } & \multicolumn{3}{|c|}{ Perlakuan } & \multicolumn{2}{|c|}{ Keterangan } \\
\hline & Kontrol & $\begin{array}{l}\text { (+) Campuran } \\
\text { hijauan }\end{array}$ & Rataan & SEM & Nilai $P$ \\
\hline Kons. Bahan kering, g/hari & $1049.32 \pm 13.75$ & $1057.36 \pm 14.34$ & 1053.63 & 14.13 & 0.078 \\
\hline Bobot badan awal, kg & $40.13 \pm 2.63$ & $39.18 \pm 1.71$ & 39.61 & 2.23 & 0.186 \\
\hline Bobot badan akhir, kg & $45.45 \pm 2.82$ & $45.87 \pm 2.17$ & 45.63 & 2.54 & 0.516 \\
\hline $\mathrm{PBBH}, \mathrm{g} / \mathrm{h}$ & $76.13 \pm 8.58^{\mathrm{b}}$ & $95.54 \pm 13.88^{\mathrm{a}}$ & 86.05 & 11.67 & $<0.0001$ \\
\hline Rasio konversi pakan & $13.96 \pm 1.63^{\mathrm{b}}$ & $11.28 \pm 1.55^{\mathrm{a}}$ & 12.59 & 1.6 & $<0.0001$ \\
\hline
\end{tabular}

Data Tabel 3 menunjukkan bahwa nilai pertambahan bobot badan harian (pbbh) induk kambing PE kelompok perlakuan lebih besar dibandingkan kelompok kontrol dengan nilainya masing-masing adalah $95,54 \pm 13,88 \mathrm{~g} / \mathrm{e} / \mathrm{h}$ dan 76,13 $\pm 8,58 \mathrm{~g} / \mathrm{e} / \mathrm{h}$. Perbedaan pbbh ini kemungkinan berkaitan dengan tingkat konsumsi nutrein harian seprti yang telah dibahas sebelumnya. Hal ini mengindikasikan bahwa walaupun total konsumsi bahan kering tidak berbeda nyata, namun adanya perbedaan tingkat konsumsi nutrien ternyata dapat menghasilkan nilai pertambahan bobot badan yang berbeda pula. Hasil percobaan ini memberikan gambaran bahwa adanya tambahan campuran dari beberapa hijauan terutama daun-daunan memberi pengaruh positif terhadap tampilan atau kinerja induk kambing PE.Kondisi ini sejalan dengan yang dilaporkan Krisnan dkk.(2015) bahwa pemberian hijauan berupa daun lamtoro menunjukkan hasil evaluasi kecukupan nutrien pada kambing Peranakan Etawa laktasi yang lebih baik.

Pertambahan bobot badan harian (pbbh) mempunyai korelasi positif terhadap tingkat rasio konversi pakan (RKP).Berdasarkan hasil analisa yang tersaji pada Tabel 3 terlihat bahwa pemberian tambahan campuran hijauan nyata berpengaruh $(\mathrm{p}<0.05)$ terhadap nilai rasio konversi pakan. RKP yang dihasilkan dari masing-masing kelompok perlakuan adalah 13,96 untuk kelompok kontrol dan 11,28 untuk kelompok yang diberi tambahan campuran hijauan. RKP adalah gambaran dari tingkat efisiensi penggunaan pakan yang diperoleh dari hasil perbandingan antara konsumsi dan pbbh. Oleh karena itu, semakin tinggi pbbh akan menghasilkan RKP yang lebih baik atau penggunaan pakan yang lebih efisien.

\section{KESIMPULAN}


Pemberian tambahan campuran hijauan tidak mempengaruhi $(p>0.05)$ konsumsi harian bahan kering (BK), namun mempengaruhi $(\mathrm{p}<0.05)$ konsumsi harian nutrient pakan, $\mathrm{PBBH}$ dan rasio konversi pakan (RKP). Konsumsi harian PK dan TDN untuk kelompok perlakuan adalah 153,25 g dan 717,78 g, sedangkan kelompok kontrol adalah $131,35 \mathrm{~g}$ dan $699,96 \mathrm{~g}$. Besarnya PBBH dan RKP adalah 95,54 g dan 11,$28 ; 76,13 \mathrm{~g}$ dan 13,96 untuk masingmasing kelompok perlakuan dan kontrol. Disimpulkan bahwa penambahan campuran hijauan pakan dapat meningkatkan tampilan (performance) yang labih baik pada induk kambing PE.

\section{DAFTAR PUSTAKA}

(AOAC) - Association of Official Analytical Chemists.1995. Official Methods of Analysis. $16^{\text {th }}$ edn.Association of Official Analytical Chemists, Arlington.

(AOAC) - Association of Official Analytical Chemists 2005.Official Methods of Analysis. $18^{\text {th }}$ edn. Association of Official Analytical Chemists, Maryland.

Devendra C. 2012. Dairy Goats in Asia: Multifunctional Relevance and Contribution to Food and Nutrition Security. In: Raseede Abdullah, Arif Omar M, Makkar H, Otte J, Ali Rajion M, Razak Alimon A, Liang JB, Haw AK, Chen WL, editors. Proceedings of the 1st Asian-Australasian Dairy Goat Conference.April 9 - 12, 2012 Kuala Lumpur (Malaysia).Universiti Putra Malaysia and FAO.p 1-6.

Diwyanto K. 2014. Bangun Karso's Dairy Goat Farming Practices in BogorIndonesia. In: Wiryawan KG, Liang JB, Takahashi J, Orskov ER, Devendra C, Toharmat T, Sutama I-K, Kustantinah, Purnomoadi A, Manalu $\mathrm{W}$, editors. The role of dairy goat industry on food security, sustainable agricultural production and economic communities.Proceeding The 2nd Asian-Australasian Dairy Goat Conference. Bogor, 25-27 April. 2014. Bogor (Indonesia): Bogor Agricultural University.p 86-92.

Iwantoro S. 2014. Government Policy on Dairy Goat Development in Indonesia.In: Wiryawan KG, Liang JB, Takahashi J, Orskov ER, Devendra C, Toharmat T, Sutama I-K, Kustantinah, Purnomoadi A, Manalu $\mathrm{W}$, editors. The role of dairy goat industry on food security, sustainable agricultural production and economic communities.Proceeding The 2nd Asian-Australasian Dairy Goat Conference. Bogor, 25-27 April. 2014. Bogor (Indonesia): Bogor Agricultural University.p 1-6.

Krisnan R, Praharani L, Supriyati, dan Pangestuti AK. 2015. Kecukupan Nutrien Kambing Peranakan Etawah Periode Laktasi. Prosiding Seminar Nasional. Puslitbang Peternakan

(NRC)-National Research Council. 2007. Nutrient Requeriments of Small Ruminants: sheep, goats, cervids, and new world camelids. 7th ed. National Academic Press.Washington, D.C.

Park YW. 2012. Goat Milk and Human Nutrition. In: Raseede Abdullah, Arif Omar M, Makkar H, Otte J, Ali Rajion M, Razak Alimon A, Liang JB, Haw AK, Chen WL, editors. Proceedings of the 1st Asian-Australasian Dairy Goat Conference.April 9 - 12, 2012 Kuala Lumpur (Malaysia). Universiti Putra Malaysia and FAO p 31-38.

Praharani L. 2014. Milk Yield of Anglo Nubian, Saanen X Etawah Grade and Etawah Grade Raised in the Same Environment. In: Subandriyo, Kusmartono, Santosa KA, Kurnianto E, Purnomoadi A, Sodiq A, Wiryawan KG, Darodjah S, Inounu I, Darmono, Priyanti A, Wynn P, Jian LH, Jih TayHsu, Idrus Z. editors. Sustainable livestock production in the perspective of food security, policy, genetic 
resources, and climate change.Proceedings of the 16th AAAP Animal Science Congress.10-14 November 2014, Gadjah Mada University, Yogyakarta (Indonesia).Ministry of Agriculture, ISPI and UGM Jogjakarta.p 1527-1530.

Rufino MOA, Alves AA, Rodrigues MM, Moura RL, Cavalcante ACR, Rogério MCP. 2012. Goat milk production and quality on Tanzania-grass pastures, with supplementation. Acta Scintiarum Anim Sci. 34 (4): 417-423.

SAS Institute Inc. 2002.SAS/STAT User's Guide.Version 9.1.SAS Institute Inc., Cary, NC, USA.

Supriyati, PuastutiW, SutamaI-K, BudiarsanaIGM, MathiusI-W, Lubis D. 2008. The effect of giving Camackarel oil on productivity, milk production and quality of PE goat. In: Yulistiani D, Sutama I-K, Wina E, Puastuti W, Praharani L, editors. Improved Dairy and Meat Goat Production.Proceedings of Internartional Seminar on Production Increase in Meat and Dairy Goats by Incremental Improvements in Technology and Infrastructure for Small-scale Farmers in Asia.August 48, 2008, Bogor (Indonesia).TheFFTCAsian and Pacific Region, IRIAP Indonesia, LRI /COA-Taiwan ROC.p 21-24.

Sutama I-K. 2014. Dairy Goat Production on Smallholder Agriculture in Indonesia. In: Wiryawan KG, Liang JB, Takahashi J, Orskov ER, Devendra C, Toharmat T, Sutama K, Kustantinah, Purnomoadi A, Manalu W, editors. The role of dairy goat industry on food security, sustainable agricultural production and economic communities.Proceeding The 2nd Asian-Australasian Dairy Goat Conference. Bogor, 25-27 April. 2014. Bogor (Indonesia): Bogor Agricultural University.p 8-17.

Sutama I-K. 2008. Pemanfaatan sumberdaya ternak lokal sebagai ternak perah mendukung peningkatan produksi susu nasional. Wartazoa 18 (4): 207-217. 